\title{
THE COMPOSITION OF GROWTH MATTERS FOR POVERTy Alleviation*
}

Norman Loayza

The World Bank
Claudio Raddatz

The World Bank

\begin{abstract}
This paper contributes to explain the cross-country heterogeneity of the poverty response to changes in economic growth. It does so by focusing on the structure of output growth itself. The paper presents a two-sector theoretical model that clarifies the mechanism through which the sectoral composition of growth and associated labor intensity can affect workers' wages and, thus, poverty alleviation. Then, it presents cross-country empirical evidence that analyzes, first, the differential poverty-reducing impact of sectoral growth at various levels of disaggregation, and, second, the role of unskilled labor intensity in such differential impact. The paper finds evidence that not only the size of economic growth but also its composition matters for poverty alleviation, with the largest contributions from labor-intensive sectors (such as agriculture, construction, and manufacturing). The results are robust to the influence of outliers, alternative explanations, and various poverty measures.
\end{abstract}

Keywords: Poverty, economic growth, production structure, labor intensity.

World Bank Policy Research Working Paper 4077, December 2006

The Policy Research Working Paper Series disseminates the findings of work in progress to encourage the exchange of ideas about development issues. An objective of the series is to get the findings out quickly, even if the presentations are less than fully polished. The papers carry the names of the authors and should be cited accordingly. The findings, interpretations, and conclusions expressed in this paper are entirely those of the authors. They do not necessarily represent the view of the World Bank, its Executive Directors, or the countries they represent. Policy Research Working Papers are available online at http://econ.worldbank.org.

\footnotetext{
* We are grateful to Yvonne Chen and Siyan Chen for research assistance and to Koichi Kume for editorial assistance. For useful comments, suggestions, and/or data we are indebted to Maros Ivanic, Francisco Ferreira, Oded Galor, Aart Kraay, Humberto López, Ross Levine, Martin Ravallion, Yona Rubinstein, Luis Servén, and seminar participants at Brown University and the World Bank. Support from the Chief Economist Office of the Latin America and Caribbean Region of the World Bank is gratefully acknowledged.
} 


\section{The Composition of Growth Matters for Poverty Alleviation}

\section{Introduction}

There is little doubt that economic growth contributes significantly to poverty alleviation. The evidence is mounting and coming from various sources: cross-country analyses (Besley and Burgess, 2003; Dollar and Kraay, 2005; Kraay, 2005; and López, 2004), cross-regional and time-series comparisons (Ravallion and Chen, 2004; Ravallion and Datt, 2002), and the evaluation of poverty evolution using household data (Bibi, 2005; Contreras, 2001; Menezes-Filho and Vasconcellos, 2004). At the same time, it is clear that the effect of economic growth on poverty reduction is not always the same. In fact, most studies point to considerable heterogeneity in the poverty-growth relationship, and understanding the sources of this divergence is a growing area of investigation (Bourguignon, 2003; Kakwani, Khandker, and Son, 2004; Lucas and Timmer, 2005, Ravallion, 2004). Most of the received literature focuses on socio-economic conditions of the population as determinants of the relationship between growth and poverty reduction. Thus, wealth and income inequality, literacy rates, urbanization levels, and morbidity and mortality rates, among others, have been found to influence the degree to which output growth helps reduce poverty.

In this paper we take a different, albeit complementary, perspective on the sources of heterogeneity in the poverty-growth relationship. We focus on the characteristics of output growth itself, rather than the demographic, social, or economic conditions of the population. We study how the production structure of the economy and, specifically, the sectoral composition of growth affect its capacity to reduce poverty. Our conjecture is that growth in certain sectors is more poverty reducing than growth in others and that a sector's poverty-reducing capacity is related to its intensity in the employment of unskilled labor.

There are important studies that precede and motivate our work. Thorbecke and Jung (1996) develop a social-accounting method to estimate the impact of various production activities on poverty reduction. The method requires knowledge of complex elasticities connecting the distribution of households with eight employment and production sectors. The authors apply the method to Indonesia in the 1980s and find that 
agricultural and service sectors contribute more to poverty reduction that industrial sectors do. Khan (1999) applies the same methodology to study sectoral growth and poverty alleviation in South Africa. He finds that higher contributions are derived from growth in agriculture, services, and some manufacturing sectors.

A different approach consists of conducting reduced-form analysis on time-series data for individual countries. This is the approach taken by Ravallion and Datt (1996) to study the evolution of poverty in India during 1951-91. Linking poverty changes to value-added growth rates in the three major sectors of economic activity, they find that growth in agriculture and services helped reduce poverty in both urban and rural areas whereas industrial growth did not reduce poverty in either. Applying a similar methodology for the case of China over 1980-2001, Ravallion and Chen (2004) find that growth in agriculture emerges as far more important than growth in secondary or tertiary sectors for the purpose of poverty alleviation.

Our work adds to this literature along four dimensions. First, we present a twosector theoretical model that clarifies the mechanism through which the sectoral composition of growth and associated labor intensity can affect workers' wages --and, thus, poverty alleviation-- even in the absence of market segmentation. Second, we use cross-country evidence --with the pros and cons associated with increasing the underlying variation of the data-- allowing us to relate our results to the empirical macroeconomic literatures on growth and poverty. Third, we employ a level of disaggregation that explores the diversity within the industrial sector, hoping to shed light on why it appears to be less pro poor than agriculture or services. And, fourth, we explicitly consider sectoral employment intensity as the mechanism through which the pattern of growth matters for poverty alleviation.

The plan of the paper is the following. Section II presents a theoretical model that formalizes our initial conjecture. It examines the wage (poverty) effect of output growth in a two-sector economy, where capital and labor are freely mobile and the sectors' technologies vary according to their labor intensity. Section III presents cross-country empirical evidence that analyzes, first, the differential poverty-reducing impact of sectoral growth at various levels of disaggregation, and, second, the role of unskilled labor intensity in such differential impact. Also in this section, we subject our basic 
result to a comprehensive set of robustness checks that account for the influence of outlier and extreme observations, for potential alternative explanations, and for various poverty measures. Section IV offers some concluding remarks.

\section{The Model}

We now present a two-sector model with asymmetric technologies to help us understand the relation between sectoral growth and poverty alleviation. We focus on the two-sector case for simplicity, but the results are analogous for the n-sector case.

The economy is populated by two types of individuals: poor and rich. Both types are endowed with $n$ units of labor, derive utility from the consumption of a final good, and have the same discount factor $\rho$ and instantaneous utility function $u(c)=\log (c)$. However, only rich individuals have access to an asset $a$ that allows them to transfer wealth across periods. This setting implies that the income and consumption of poor individuals depend only on the real wage rate. Thus we assume that the rate of poverty reduction is related only to the growth rate of real wages. Although this is an extreme assumption, it simplifies considerably the analysis and is roughly consistent with the low saving rates observed both in poor countries and poor households within a country. ${ }^{1}$

The final good, $y$, is produced by a perfectly competitive firm using a constantreturns-to-scale technology and two intermediate goods, $y_{1}$ and $y_{2}$, as inputs according to

$$
y=\left(y_{1}^{\beta}+y_{2}^{\beta}\right)^{\frac{1}{\beta}}
$$

The final good can be used not only for consumption but also as capital in the production of the intermediate goods. Each intermediate good is produced by a perfectly competitive firm according to the following technology with labor-augmenting technological progress,

\footnotetext{
${ }^{1}$ Schmidt-Hebbel and Serven (1999) show that saving rates increase with income across countries. In poor countries, the saving rates are below 10\%. Attanasio and Székely (1998) provide evidence on households' saving rates at different levels of the income distribution in Mexico. Their data show that saving rates increase strongly with income and display even negative values up to the 25th percentile of the household income distribution.
} 


$$
y_{i}=k_{i}^{\left(1-\alpha_{i}\right)}\left(A_{i} n_{i}\right)^{\alpha_{i}}, i=1,2
$$

where $k_{i}$ and $n_{i}$ are sector $i$ 's capital and labor, respectively, and $A_{i}$ captures the level of technology, which evolves exogenously according to $A_{i}=\exp \left(g_{i} t\right)$. We assume that capital is perfectly mobile across sectors and does not depreciate.

\section{Intersectoral allocation}

In what follows we use this setup to derive the relation between the composition of growth and the evolution of the real wage rate, which given our assumptions maps into the income and consumption of the poor. We will only focus on the aspects of the model that are relevant for the derivation of this expression and omit several side aspects of the characterization.

Under perfect competition, the price charged by the final-good firm, $p$, equals its unit cost of production. Then,

$$
p=\left(p_{1}^{1-\varepsilon}+p_{2}^{1-\varepsilon}\right)^{\frac{1}{1-\varepsilon}}
$$

where $\varepsilon=(1-\beta)^{-1}$. Solving the optimization problem of the final-good firm and setting the price of the final good as a numeraire, we obtain the following first order conditions,

$$
\frac{p_{i} y_{i}}{Y}=s_{i}=\left(\frac{y_{i}}{Y}\right)^{\frac{\varepsilon-1}{\varepsilon}}, i=1,2
$$

which characterize the share of the final good production value that goes to each intermediate sector. Given that the production of the final good exhibits constant returns to scale these shares add up to one.

Combining the first order conditions, we obtain the following expression for the demand of intermediate goods,

$$
\frac{y_{1}}{y_{2}}=\left(\frac{p_{2}}{p_{1}}\right)^{\varepsilon},
$$


which shows that $\varepsilon$ corresponds to the (constant) elasticity of substitution between the intermediate goods. Under perfect competition, each intermediate-good firm determines its demand for labor and capital taking factor and output prices as given. Then, the firstorder conditions corresponding to the intermediate-good firm are given by

$$
y_{i}=\frac{\omega n_{i}}{p_{i} \alpha_{i}}=\frac{r k_{i}}{p_{i}\left(1-\alpha_{i}\right)}, i=1,2,
$$

Equations (2) and (3)--which correspond to the standard conditions for static efficiency-- plus the conditions of factor market equilibrium -- $k_{1}+k_{2}=k$, and $n_{1}+n_{2}=n$-- determine the allocation of labor and capital across sectors at every moment.

Although in principle we could use the previous equations to determine the relative prices of the intermediate goods $p_{1} / p_{2}$ as a function of the aggregate capitallabor ratio $k / n$, technological parameters, and sector productivities $A_{i}$, this problem cannot be solved in closed form except in some special cases that restrict the values of $\varepsilon$ and the $\alpha_{i}$ (see Miyagiwa and Papageorgiu, 2005, for a discussion). Nevertheless, we can use these equations to characterize the evolution of real labor income, which is the object of interest for our empirical analysis.

\section{The evolution of real labor income}

According to the first-order conditions for intermediate-good firms, and focusing without loss of generality on intermediate good 1 , the rate of change of the real wage can be written as

$$
\hat{\omega}=\hat{p}_{1}+\hat{y}_{1}-\hat{n}_{1}
$$

where the hat denotes the rate of change of a variable $(\hat{x}=d x / x)$. The first two terms of this expression correspond to the evolution of the value of sector 1 output in terms of the final good $\left(p_{1} y_{1}\right)$. From equation (1) this corresponds to

$$
\hat{s}_{1}+\hat{Y}=\frac{\varepsilon-1}{\varepsilon} \hat{y}_{1}+\frac{1}{\varepsilon}\left(s_{1} \hat{y}_{1}+s_{2} \hat{y}_{2}\right)
$$

where we have used the fact that $\hat{Y}=s_{1} \hat{y}_{1}+s_{2} \hat{y}_{2}$ because of constant returns to scale. 
The last term in equation (4) is the evolution of employment in sector 1 . The first order conditions of intermediate good firms with respect to labor presented in equation (3) together with equation (2) imply that

$$
\left(\frac{\alpha_{1}}{\alpha_{2}}\right)\left(\frac{n_{2}}{n_{1}}\right)\left(\frac{y_{1}}{y_{2}}\right)^{\frac{\varepsilon-1}{\varepsilon}}=1,
$$

which, after log-differencing and using the labor market clearing condition $n=n_{1}+n_{2}$, results in the following expression for the growth rate of employment in sector 1 ,

$$
\hat{n}_{1}=l_{2} \frac{\varepsilon-1}{\varepsilon}\left(\hat{y}_{1}-\hat{y}_{2}\right)+\hat{n},
$$

where $l_{2}$ is the share of employment in sector $2\left(n_{2} / n\right)$.

Finally, putting together equations (5) and (7) and re-arranging terms we obtain the growth rate of the real wage rate,

$$
\hat{\omega}=\sum_{i=1}^{2} s_{i} \hat{y}_{i}+\left(\frac{\varepsilon-1}{\varepsilon}\right) \sum_{i=1}^{2}\left(l_{i}-s_{i}\right) \hat{y}_{i}
$$

where, in a slight abuse of notation, $\hat{y}_{i}$ now represent the growth rates in per-capita terms.

This equation indicates that the growth of real labor income is driven by two components. The first one, corresponding to the first term on the left-hand side of equation (8), is the growth of per-capita GDP. An increase in per-capita GDP corresponds to a higher output per worker that maps into higher wages. The contribution of a sector's growth to this term depends exclusively on its size, as captured by its share on final-good output, $s_{i}$. The second component captures the reallocation effects. The impact of a sector's growth on this component depends on the elasticity of substitution across sectors in the production of the final good $(\varepsilon)$ and on a sector's labor intensity, as captured by the difference between its labor share of total employment, $l_{i}$, and its share in total output $s_{i}$. Starting from equations (1) and (3), it can be shown that this difference corresponds to 


$$
l_{i}-s_{i}=\frac{1}{1+\left(\frac{\alpha_{-i}}{\alpha_{i}}\right)\left(\frac{s_{i}}{s_{-i}}\right)}-\frac{1}{1+\left(\frac{s_{i}}{s_{-i}}\right)}, i=1,2
$$

which indicates that the difference $l_{i}$-S $S_{i}$ is higher for sectors with a higher share of labor in total output, $\alpha_{i}$. This means that growth in a labor intensive sector will have an additional effect on wages beyond its impact on aggregate growth, as long as the elasticity of substitution is sufficiently high (specifically above 1 , according to eq. (8)). ${ }^{2}$

The elasticity of substitution is relevant because it determines whether (and by how much) labor will move into or out of a growing sector: the higher the elasticity of substitution, the more labor moves into that sector. If the elasticity is too low (below 1) labor actually moves out of an expanding sector; however, as the elasticity increases and surpasses a threshold value (equal to 1), labor starts to flow into the growing sector. With a high (low) elasticity of substitution, the price adjustment required by an increase in the relative output of a sector is small (large) so that labor needs to move into (out of) the expanding sector to achieve wage equalization (this can be clearly seen in eq. (6)).

Equation (8) also shows that there are two cases in which the growth rate of real labor income depends only on GDP growth: (i) when the technologies of the intermediate sectors are identical $\left(\alpha_{1}=\alpha_{2}\right)$, and (ii) when the elasticity of substitution is equal to one (the Cobb-Douglas case). The first case is trivial: if there are no asymmetries across sectors, uneven growth is irrelevant. In the second case, under a Cobb-Douglas production function, sectoral labor shares are constant, and any adjustment in relative quantities results only in a corresponding change in relative prices. Uneven sectoral growth, not requiring labor reallocation across sectors, would not affect real wages. Thus, omitting the composition of growth as a determinant of real wage increases and poverty alleviation is equivalent to assuming that either sectors do not differ in their labor intensities or their elasticity of substitution is equal to one.

Although not explicitly derived in the model, it should be noted that the presence of technological progress is important for the long-run implications of the model (that is,

\footnotetext{
${ }^{2}$ Consider the following example. Suppose that sector 1 is more labor intensive than sector $2\left(\alpha_{1} / \alpha_{2}>1\right)$, so that $\mathrm{l}_{1}-\mathrm{s}_{1}>0$, and that it experiences an exogenous increase in productivity. If the elasticity of substitution is sufficiently high, labor will move into sector 1 where it is relatively more productive, pushing the wage rate up. The opposite will happen if the elasticity of substitution is relatively low (below 1).
} 
beyond transitional dynamics). If the model exhibits a balanced-growth path, the growth rate of each sector $\hat{y}_{i}$ and of the economy will be exclusively determined by the growth rates of productivity in all the different sectors of the economy (the $g_{i} \mathrm{~s}$ ). Characterizing the balanced growth path of the model is beyond the scope of this paper; nevertheless, equation (8) is valid both during transitional dynamics and in balanced growth.

Our assumption that poverty changes are only a function of the growth rate of real labor income corresponds to assuming that $\hat{h}=\psi(\hat{\omega})$, where $\hat{h}$ is the growth rate of poverty. In the empirical section of the paper, we will estimate the parameters of the linearized version of this relation $\hat{h}=\gamma_{0}+\gamma_{1} \hat{\omega}$ as our benchmark case, but we will also consider some non-linear relations in our robustness analysis.

\section{Empirical Evidence}

Our empirical analysis consists of two related sections. In the first, we address the connection between the pattern of growth and poverty alleviation by disaggregating growth into its sectoral components and examining their corresponding effects on poverty. This is the traditional approach, and, thus, it allows us to place our analysis in the context of the received literature. The second empirical section modifies the sectoral analysis by introducing labor intensity as the source of the differential impact of sectoral growth on poverty reduction. This approach is derived from the theoretical model and, thus, establishes the link between theory and empirics in the paper.

\section{Data and sample}

Our sample consists of a cross-section of developing countries with comparable measures of poverty changes, disaggregated value-added growth rates at 3-and 6-sector levels, and unskilled employment at the same levels of disaggregation. In practice, our dataset is the result of combining the Kraay (2005) database on poverty spells, ${ }^{3}$ World

\footnotetext{
${ }^{3}$ The Kraay database results from processing income distribution data for a large number of developing countries. In turn, its source is the collection of household survey data estimated from primary sources and made comparable across countries by Martin Ravallion and Shaohua Chen at the World Bank. For details, see Kraay (2005).
} 
Bank (2005) data on sectoral value added, ${ }^{4}$ and Purdue University’s Global Trade Analysis Project database (GTAP, 2005) on labor shares.

We focus on changes occurring over long horizons, where the poverty reductioneconomic growth relationship is most stable. For this reason we use only one spell per country, where the duration of the spell corresponds to the longest period for which initial and final poverty data exist for the country. The rest of the variables (e.g., value added growth rates and labor ratios) are calculated over the corresponding period per country.

The dependent variable is the proportional change in poverty over a period of time (spell) per country. Specifically, this is the annualized change in poverty as proportion to average poverty over the period. ${ }^{5}$ Given its importance in the literature, the benchmark poverty measure in the paper is the headcount poverty index, defined as the fraction of the population with income below a given poverty line. In robustness exercises, however, we use alternative measures of poverty, comprising other members of the Foster-Greer-Thorbecke class of measures (the poverty gap and the squared poverty gap) and the Watts index. Following convention for cross-country comparability, the poverty line is set to $\$ 1$ per person per day, converted into local currency using a purchasing-power-parity adjusted exchange rate.

Regarding the explanatory variables, we work with growth rates of sectoral valueadded and employment data at two levels of disaggregation. The first is the traditional sectoral division of agriculture, industry, and services. The second one disaggregates industry further into mining, manufacturing, utilities, and construction. Sectoral growth rates are calculated directly from data on sectoral value added as annualized log changes of per capita value added between the end and start of the corresponding spell. Employment data is calculated indirectly from data on sectoral value added and payments

\footnotetext{
${ }^{4}$ The World Bank (2005) data on sectoral value added is complemented with statistics from the InterAmerican Development Bank and the United Nations.

${ }^{5}$ That is, proportional poverty change $=\frac{1}{T} * \frac{P_{F}-P_{I}}{\left(P_{F}+P_{I}\right) / 2}$, where $P$ represents the poverty measure; $T$, the length of the spell; and the subscripts $I$ and $F$, initial and final, respectively. Calculating the proportional change with respect to the average measure allows us to avoid abnormally large proportional changes when very low initial and/or final measures are present, as would be the case if log differences were used. Kraay (2005) uses the latter procedure and then is forced to drop a considerable number of observations. Were we to use Kraay's method, we would be working with 32 country observations, rather than 51, the sample size of our benchmark regression.
} 
to unskilled workers. Under the assumption of wage equalization, the ratio of unskilled workers in a sector to total unskilled workers in the country is calculated as the ratio of payments to unskilled workers in the sector to total payments to unskilled workers in the economy. Regarding data for this calculation, only one observation per country or per similar countries is available from the original source (GTAP). ${ }^{6}$

The resulting sample consists of 55 countries for 3-sector data and 51 countries for 6-sector data. Appendix 1 provides the list of countries included in the sample, as well as the initial and final years of their corresponding spell. Appendix 2 provides definitions and sources for all variables used in our empirical exercises, and Appendix 3 presents basic summary statistics on the 51-country sample.

\section{Poverty reduction and sectoral growth}

We are interested in estimating the effect of sectoral growth on poverty reduction. The regression equation can then be written as,

$$
\hat{h}_{j}=\delta_{0}+\sum_{i=1}^{I} \delta_{i} \cdot s_{i j} \cdot \hat{y}_{i j}+\varepsilon_{j}
$$

where $\hat{h}$ is the annualized rate of change of the headcount poverty index, $\hat{y}$ is the annualized rate of change of sectoral value added, $s$ is the sectoral value added share in GDP, and the subscript $i$ and $j$ represent sector and country, respectively. All growth rates are expressed in per capita terms, and the sector shares are calculated from constantprice magnitudes. ${ }^{7}$ The set $I$ consists of three or six sectors, depending on whether industry is considered as a whole or disaggregated into its four major categories. In principle, it may be possible to estimate the poverty effect of output changes in a levels

\footnotetext{
${ }^{6}$ Given that, in most cases, the date of this observation differs significantly from the years of our poverty spell, we first use the GTAP data to compute the ratio of payments to unskilled workers to a sector's value added and assume it to be constant over time, for a given sector and country. We then use this ratio and the sector's share in total value added during our spell (from World Bank, 2005) to compute the corresponding ratio of unskilled workers in the sector to total unskilled workers in the country. Under wage equalization, the ratio of unskilled workers in a sector to total unskilled workers can be written as $l_{k} / l=\alpha_{k} s_{k} / \sum_{i} \alpha_{i} s_{i}$, where $\alpha_{k}$ is the ratio of unskilled labor payments to sector's $k$ value added, and $s_{k}$ is the share of sector $k$ in total value added.

${ }^{7}$ Calculating the shares from nominal magnitudes would more closely approximate the theoretical model. However, we work with constant-price shares because, first, their resulting country coverage is larger than when using current-price shares, and, second, they are very similar and render basically the same econometric results.
} 
regression. However, the literature advices a regression in differences to control for fixed effects that may be driving both poverty and output, such as a host of country-specific development-related variables in our cross-country setting.

Our regression specification weights sectoral growth by its relative size. As Ravallion and Chen (2004) point out, this specification has the advantage that it allows for a simple test of whether the growth composition matters: If the null hypotheses that the coefficients $\delta_{i}$ are equal to each other cannot be rejected, then the sectoral regression collapses to one where GDP growth is the only relevant explanatory variable. In this case, only size and not composition of growth would matter for poverty alleviation. Our regression specification also allows for testing whether these sectors can be grouped in different categories, not according to their output characteristics but according to their relationship with poverty reduction. This will become important when we study the case of six-sector disaggregation.

Table 1 presents the results when GDP is decomposed into agriculture, industry, and services. The regressions are conducted using both the full sample of 55 countries and the subset of 51 countries for which six-sector data are available. The latter exercise is conducted with the purpose of comparison with the six-sector analysis. In both samples (columns 1 and 3, respectively), the size-adjusted value-added growth rates of all sectors fail to carry statistically significant coefficients. Moreover, the hypothesis that the coefficients are the same cannot be rejected.

The lack of individual significance of sectoral growth rates and the inability to separate their effects indicates that the three major sectors are highly linked in their relationship with poverty reduction. This may be interpreted as evidence against the importance of growth composition for poverty alleviation, but it may also be the result of working with insufficiently disaggregated output categories. We examine the latter possibility below when we analyze the six-sector case. Before doing that, however, we can take the failure to reject the equality of coefficients at face value and estimate a constrained regression that assumes equal sectoral effects. Apart from approximation errors, this is equivalent to regressing poverty changes on GDP growth rates. These results are presented in columns 2 and 4 for each of the samples, respectively. In both 
cases the growth elasticity of poverty is negative, statistically significant, and a little over 1 in magnitude.

Table 2 presents the results when GDP is further disaggregated into agriculture, services, and industry's four major categories. We work with both the full sample of countries and the reduced sample obtained by applying the Kraay (2005) criteria for eliminating extreme observations (see footnote 4). The results are similar in both cases, so we discuss only those using the full sample. In the unconstrained regression, only manufacturing growth carries a significantly negative coefficient, although agriculture growth also approaches a level of significant poverty alleviation effect. The pattern of signs is diverse across sectors, with agriculture, manufacturing, and construction, carrying negative coefficients, while mining, utilities, and services presenting positive ones.

The relatively large dispersion across countries makes it difficult to learn much about differences in growth elasticities of poverty across sectors unless we restrict the model to be estimated. We can do this by pulling together sectors that appear to have similar effects on poverty. A first approximation is to group together sectors that present negative coefficients in the unconstrained regression, and do likewise with those that carry positive coefficients. Before grouping them, we can test the equality of their coefficients. These tests (shown at the bottom of Table 2, column 1) indicate that agriculture, manufacturing, and construction (the sectors carrying negative coefficients) can be pulled together, while mining, utilities, and services (all carrying positive coefficients) can form a single category.

Applying these restrictions, we can estimate the corresponding constrained regression, whose results are presented in column 2. Growth in agriculture, manufacturing, and construction now appear to have a clear, significant poverty reducing effect. In contrast, growth in mining, utilities, and services do not seem to reduce poverty (or worsen it for that matter), once growth in other sectors is controlled for. The test for the equality of coefficients in the constrained regression confirms that the two groups (agriculture/manufacturing/construction on one side and mining/utilities/services on the other) have statistically different impacts on poverty (see bottom of columns 2 and 4). 


\section{Poverty reduction and labor-intensive growth}

Why would some sectors' growth contribute to poverty alleviation more than growth in others? There are a few potential explanations. One is the relationship between the geographic location of a sector's production and the incidence of poverty in the area. According to this argument, agricultural growth would have a large impact on poverty alleviation because the poor are concentrated in rural areas. A second explanation emphasizes market segmentation, which would prevent wage gains in one sector to be transmitted to the rest. Our theoretical model formalizes a third explanation according to which a sector's labor intensity determines its impact on poverty reduction, even in the presence of free labor mobility.

The basic result of our theoretical model links wage increases to sectoral growth and is given in equation (9). The multi-sector version of this equation can be written as,

$$
\hat{\omega}=\left(\sum_{i=1}^{I} s_{i} \cdot \hat{y}_{i}\right)+\left(\frac{\varepsilon-1}{\varepsilon}\right)\left(\sum_{i=1}^{I}\left(l_{i}-s_{i}\right) \cdot \hat{y}_{i}\right)
$$

That is, wage grows proportionally to aggregate output (first term) with a premium (second term) if growing sectors are sufficiently labor intensive. Assuming that wage increase and poverty reduction are linearly related, $\hat{h}=\theta_{0}+\theta_{1} \hat{\omega}$., then changes in poverty can be expressed as a function of sectoral growth,

$$
\hat{h}=\theta_{0}+\theta_{1}\left(\sum_{i=1}^{I} s_{i} \cdot \hat{y}_{i}\right)+\theta_{2}\left(\sum_{i=1}^{I}\left(l_{i}-s_{i}\right) \cdot \hat{y}_{i}\right)
$$

Collecting terms,

$$
\hat{h}=\theta_{0}+\sum_{i=1}^{I}\left(\theta_{1}-\theta_{2}+\theta_{2} \frac{l_{i}}{s_{i}}\right) s_{i} \cdot \hat{y}_{i}
$$

This expression indicates that a sector's growth effect on poverty reduction depends on its labor intensity, $l_{i} / s_{i}$. To the extent that sectors differ concerning their labor intensities, this explains why their effects on poverty alleviation are not the same. Moreover, since in principle labor intensities can vary not only across sectors but also across countries for the same sector, then the sectoral growth elasticities of poverty reduction may be country specific. This may explain in part why our sectoral regressions are so lacking in precision. 
How different is labor intensity across sectors and across countries? And, is the pattern of sectoral growth elasticities of poverty consistent with their labor intensities? Figure 1 presents box-plots for the cross-country distribution of labor intensities $\left(l_{i} / s_{i}\right)$ corresponding to the six sectors under examination. We notice that, first, with different degrees, these sectors exhibit a remarkable dispersion across countries; and second, in spite of this dispersion, it is possible to identify a ranking of labor intensities across sectors. Agriculture and construction, followed by manufacturing, seem to be the most labor-intensive sectors, having all of them a median $l_{i} / s_{i}$ ratio larger than 1 . The construction sector is noticeable for the large dispersion of its cross-country distribution of labor intensity. Conversely, manufacturing shows a concentrated distribution, particularly regarding the inter-quartile range, which may explain why its coefficient is estimated with sufficient precision to achieve statistical significance. Mining and utilities, followed by services, are the least labor-intensive sectors, with median $l_{i} / s_{i}$ ratios below 1 in all cases. Mining and utilities also show considerable dispersion across countries in their labor intensity, while services presents the most concentrated distribution of the six major sectors.

The pattern of coefficients on sectoral growth estimated above is consistent with the notion that labor intensity determines a sector's influence on poverty alleviation. The sectors with median labor intensities greater than 1 --agriculture, construction, and manufacturing-- carry negative coefficients; while those with median labor intensities lower than 1 --mining, utilities, and services-- have positive coefficients. Moreover, the ranking of labor intensities (in decreasing order) coincides exactly with the ranking of sectoral coefficients (from more to less negative) estimated for the reduced sample and with those estimated for the full sample with only one exception (mining and services switch places).

The consistency between labor intensities and the pattern of estimated sectoral growth coefficients is suggestive, but a more formal test can be conducted on the basis of out theoretical model. Equation (12) can be written as a regression equation of the change in poverty on aggregate and sectoral growth, 


$$
\hat{h}_{j}=\theta_{0}+\theta_{1} \hat{y}_{j}+\theta_{2}\left(\sum_{i=1}^{I}\left(\frac{l_{i j}}{s_{i j}}-1\right) \cdot s_{i j} \cdot \hat{y}_{i j}\right)+\varepsilon_{j}
$$

where, $\hat{y} \cong\left(\sum_{i=1}^{I} s_{i} \cdot \hat{y}_{i}\right)$ is (per capita) GDP growth. The coefficient $\theta_{1}$ indicates the size effect of growth on poverty reduction, while $\theta_{2}$ reveals its composition effect. Negative signs are expected for both coefficients if growth helps reduce poverty and if the labor intensity of growing sectors has an additional impact on poverty alleviation.

In order to estimate equation (14), it is crucial to obtain data on labor intensities by sector and country. As explained above, we derive these data from information on sectoral value added from World Bank (2005) and payments to unskilled workers from the Global Trade Analysis Project (GTAP). We focus on unskilled workers as they are likely to best represent the poor in each country.

Equation (14) provides a direct test of the model, and this is our basic and preferred specification. However, there are other possibilities. First, if we believe that labor intensities are technological driven and common across countries, then we can use a single $l_{i} / s_{i}$ ratio for each sector for all countries. This may be a good strategy if we are uncertain as to the quality of the data on labor intensities per country. We implement this specification by replacing the country-specific labor intensities in equation (16) by their corresponding sample median per sector. Second, a discrete or categorical version of the test can be derived by assuming that sectoral growth can have either a high or a low impact on poverty reduction depending on whether its labor intensity $l_{i} / s_{i}$ is, respectively, above or below a certain threshold, which we set equal to 1 . This approach is useful if we are still uncertain as to the precise measure of labor intensities but don't believe that they are common across countries. We implement this specification by allocating sectors into two groups according to their labor intensity, regressing poverty changes on the growth rates of high and low labor-intensity groups, and then testing for the difference between their respective coefficients. Notice that the composition of these groups can vary from country to country.

Table 3 presents the estimation results for the direct regression implied by the model (column 2), the two alternative specifications (columns 3 and 4), and a benchmark 
regression with (per capita) GDP growth as sole explanatory variable (column 1). The coefficients on aggregate growth $\left(\theta_{1}\right)$ are always significantly negative, with larger magnitudes when labor intensity is controlled for. Most relevant for our purposes, the coefficient on labor-intensity-weighted sectoral growth --or labor-intensive growth, for short-- $\left(\theta_{2}\right)$ is also negative and highly statistically significant in our preferred specification (column 2). Interestingly, the regression fit increases considerably (from 15 to $28 \%$ ) once information on labor intensity is added to that on aggregate growth. Figure 2 shows a partial-regression plot linking the change in poverty and labor-intensive growth; it confirms a negative pattern that is well established by most observations in the sample (we consider the issue of outliers below.) Thus, it appears that in addition to the size of growth, the composition of growth regarding its labor intensity is statistically and economically relevant for explaining poverty reduction.

The coefficient on labor-intensive growth is also negative and statistically significant when we use medians per sector across countries to measure labor intensity (column 3). However, the fit of the regression declines somewhat, revealing that country-specific data on labor intensities contribute useful information for growth composition to explain poverty changes. A similar message is obtained from the alternative specification based on grouping sectors by labor intensity (column 4). The coefficient on growth in high labor-intensity sectors is negative and statistically significant, while that on growth in low labor-intensity sectors is much smaller and not significant. In fact, the null hypothesis that these two coefficients are the same is rejected with a p-value of 0.07 . The R-squared in this case falls considerably with respect to the preferred case, confirming that the precise numerical values on country-specific labor intensities provide relevant information that cannot be captured by categorical indicators.

\section{Robustness to outliers and extreme observations}

Table 4 presents the results related to the analysis of robustness to ouliers, with our basic regression repeated in column 1 for comparison purposes. The data on labor intensity, $l_{i} / s_{i}$, present a few extreme values that are likely to represent either measurement error or rare circumstances; in order to avoid their undue influence, in our basic specification, we truncated the cross-country distribution of labor intensity per 
sector to values ranging from 5 to 95 percentile of the original distribution. Column 2 presents the regression results when these extreme values are not truncated. The coefficient on labor-intensive growth continues to be statistically negative, although its level of significance and the regression fit diminish a little.

Inspection of Figure 2 may raise questions as to the influence of some countries in our basic results. To dispel these doubts, we run the regression using a procedure that weighs observations according to how they fit the pattern established by the rest. This is the robust regression presented in column 3. We also run the regression completely excluding possible outliers, identified as the countries that receive weights below 0.7 of a maximum of 1 in the robust procedure. These countries are Argentina, Estonia, Latvia, and Senegal; and the corresponding results are shown in column 4. In both cases, the coefficient of interest remains negative and highly statistically significant, with a magnitude that is almost the same as that in the benchmark case. It is reassuring that the regression fit increases considerably when the outliers are excluded.

As mentioned above, the way we calculate poverty changes (that is, proportional with respect to the average poverty level in the spell) produces fewer extreme values than the standard way of taking log differences. This allows us to keep a larger number of observations in the sample than would be the case if we applied the criteria in Kraay (2005). We check whether our basic results still hold in this reduced sample (of 32 countries), and the results are presented in column 5. The sign, significance, and even magnitude of the coefficient on labor-intensive growth are remarkably similar as those using the full sample, with a slight gain in regression fit. All in all, the results in Table 4 allow us to conclude that our basic results are robust to the possible presence of outlier or extreme observations.

\section{Alternative explanations}

It may be argued that the importance of the growth composition term is due to its correlation with other variables that affect poverty changes. The results in Table 5 check for this possibility by allowing for alternative explanations in turn. First is the issue of agricultural growth. Given that agriculture is the sector with the highest labor intensity in most countries, it may be argued that our growth composition variable is just capturing 
the presence of agriculture, which may affect poverty reduction for reasons unrelated to labor intensity. We examine this possibility by adding (size-adjusted) agriculture value added growth as an independent explanatory variable to our basic specification (see column 1). While the coefficient on agricultural growth is negative but not statistically significant, the coefficient on labor-intensive growth retains its sign, significance, and magnitude with respect to our basic specification. This suggests that the importance of agricultural growth in poverty reduction that has been recognized in the literature is mostly due to its intensive use of unskilled labor. Most significantly, the importance of labor intensity in growth's ability to reduce poverty appears to be relevant across all sectors.

Second is the connection with inequality. A prominent explanation in the literature as to the differing effect of income growth on poverty reduction is that higher inequality dampens the beneficial impact of growth (see Ravallion 2004 for references). If more unequal countries have growth biased against labor-intensive sectors --because, for instance, inequality induces policies that make labor markets more rigid--, then excluding inequality from our analysis could be biasing the results in our favor. To account for this possibility, we control for inequality by adding the Gini coefficient as an independent explanatory variable (column 2) and by interacting it with both the growth size and composition terms (column 3). This also captures possible non-linearities in the relation between wage growth and poverty reduction. In both cases, the growth composition term remains negative and significant, as in our preferred specification. The significance of GDP growth per se suffers when the interactions with the Gini coefficient are added given its high collinearity with the interaction term.

Third is the issue of measurement error due to the discrepancy between national accounts and household surveys on data for mean income growth. As mentioned above, poverty measures are constructed from household survey information; and in most studies connecting poverty and mean income growth, the same source is used for both variables. We, however, do it otherwise: since our focus is on production and its composition, we had to use data from national accounts for the explanatory variables. It is well-known that income growth derived from household survey data shows large and sometimes systematic differences with that obtained from national accounts (see Deaton, 
2003). If these differences are correlated with labor intensity in the country, the coefficient on growth composition may be biased. Moreover, the bias could be in our favor if national accounts underreported production from unskilled workers. To account for this possibility, we include mean income growth from household surveys as an additional explanatory variable (see column 4). As expected, this variable carries a negative and significant coefficient, and its inclusion produces both an improvement in the regression fit and a decline in the magnitude of the coefficients on the size and composition of growth. However, both coefficients remain negative and statically significant, confirming our hypothesis.

Fourth is the issue of growth endogeneity. Our analysis has been conducted in differences in order to control for country-specific structural factors that affect poverty and production jointly. Still, it can be argued that improvements in poverty drive production growth --possibly through higher rates of accumulation of human capital and savings-- thus making the analysis in differences also subject to the endogeneity critique. Although this does not apply to the variable on the composition of growth, its coefficient may still be biased if composition and size of growth are correlated. To control for the potential endogeneity of growth, we instrument for it using the average GDP growth of the country's trading partners as the source of exogenous variation. The instrumental variable procedure (whose results are presented in column 5) renders coefficients on the size and labor-intensity of growth that remain negative and highly significant. Moreover, their magnitudes are even larger that in the benchmark case, indicating that the endogeneity of growth, if any, was playing against the hypothesis advocated in the paper.

\section{Alternative poverty measures}

Our analysis has used the headcount poverty index as the benchmark measure of poverty given its prominence in both the empirical literature and policy circles. However, our simple theoretical model builds the case for the importance of the composition of growth by focusing on its relationship not with poverty directly but with labor wages. The connection with poverty is made by assuming that wages affect poverty according to a linear function, which combined with the basic result of the model brings about the paper's main regression equation. Yet, the linearity of the relationship 
between wages and the headcount poverty index may be called into question by considering that the elasticity of this measure to marginal changes in income is nil except around the poverty line. (Naturally, the justification for the linear assumption in the paper is that we are dealing with more than marginal changes in income/production.) To dispel these doubts, we use other poverty measures that are more closely related to wages and that respond to changes in income over a wider range of the income distribution.

Table 6 shows the results when alternative poverty measures are used to construct the dependent variable; these measures are the average poverty gap, the average squared poverty gap, and the Watt's poverty index (columns 1-3, respectively). In all cases, the size of GDP growth and --most importantly for our purposes-- its labor intensity carry negative and quite significant coefficients. The regression fit does not improve when we use these alternative poverty measures instead of the standard headcount index; actually, the $\mathrm{R}^{2}$ is one-third lower when using the simple poverty gap. Finally, in column 4 we examine to what extent our benchmark result comes from the connection between laborintensive GDP growth and improvements in the incomes of the poor. For this purpose, we add the growth of the average poverty gap as an additional explanatory variable. We find that the growth composition term retains its sign and significance, but its size shrinks to less than one third than in the benchmark. This indicates that, at least partially, laborintensive growth affects the headcount poverty index through the incomes of the poor.

\section{The mechanism: distribution or mean component of poverty changes?}

The last issue we examine is the mechanism through which the labor intensity of GDP growth matters for poverty alleviation. In particular, does it affect the distribution or the mean component of poverty changes? To answer this question we implement the decomposition introduced by Datt and Ravallion (1992), according to which changes in poverty can be broken down into the portion due to changes in mean income holding income distribution constant (i.e., unchanged Lorenz curve), the portion due to changes in the distribution of income holding constant its mean, and an approximation residual. Then, we estimate the respective effects of the size and the labor-intensity of GDP growth on each of these components, applying the restriction that the combined effect of each explanatory variable must be the same as its corresponding effect on the overall 
poverty change (which is given by the benchmark regression). We implement this estimation through a constrained Seemingly-Unrelated-Regression-Equation procedure (SURE).

The results are presented in Table 7. When SURE estimation ignores the influence of outliers (columns 1 and 2), we find that labor-intensive growth affects poverty changes exclusively through their mean component. When we control for the influence of outliers (Cols. 3 and 4), labor-intensive growth still affects significantly the mean component, but now it appears to also affect the distribution component though less strongly and significantly. The strength of the mean-income channel relative to the distribution channel indicates that labor-intensive growth should not be associated with zero-sum income changes across households. It's not that labor-intensive growth is poverty reducing mainly because it implies redistribution from rich to poor. Although labor-intensive growth improves the relative standing of the poor, its main effect on poverty is through its beneficial impact on their absolute income.

\section{Concluding Remarks}

The first concern that developing countries face in their objective to reduce poverty is the lack of sufficient economic growth. This is justifiably so given that no lasting poverty alleviation has occurred in the absence of sustained production growth. However, growth's sheer size does not appear to be a sufficient condition for profound poverty reduction. In fact, a complaint often heard in countries around the world is that the poverty response to growth is sometimes disappointing.

A general argument for the resilience of poverty relies on either the lack of opportunities presented to the poor or their inability to take advantage of them. If the poor are malnourished, are uneducated, live in remote areas, or are discriminated against, the gains of economic growth are likely to escape them. This paper offers a complementary perspective supporting the general argument on the lack of opportunities. In a nutshell, the paper argues that not only the size of economic growth matters for poverty alleviation but also its composition in terms of intensive use of unskilled labor, the kind of input that the poor can offer to the production process. 
The paper first illustrates the connection between wage expansion (poverty reduction), labor intensity, and sectoral growth through a multi-sector theoretical model. Then, considering the model's insights, it conducts a set of cross-country empirical exercises on poverty changes as the dependent variable. The paper finds that the impact of growth on poverty reduction varies from sector to sector and that there is a systematic pattern to this variation. Sectors that are more labor intensive (in relation to their size) tend to have stronger effects on poverty alleviation. Thus, agriculture is the most poverty-reducing sector, followed by construction, and manufacturing; while mining, utilities, and services by themselves do not seem to help poverty reduction.

After this sectoral-driven empirical analysis, the paper conducts a more direct test of the model by considering poverty reduction a function of not only aggregate growth (which would represent growth's size effect) but also a measure of labor-intensive growth (which would represent its composition effect). The results confirm that poverty alleviation indeed depends on the size of growth. Moreover, they also indicate that poverty reduction is stronger when growth has a labor-intensive inclination. This central result of the paper is robust to the influence of outlier and extreme observations, holds true for various poverty measures (such as the headcount index, the average poverty gap, and the Watt's index), and is not driven away by alternative explanations --such as the importance of agricultural growth in reducing rural poverty, the role of inequality in dampening the beneficial impact of growth, and the statistical discrepancy between household surveys and national accounts. Finally, analysis on the mechanisms through which labor-intensive growth reduces poverty allows us to conclude that this positive effect does not require or imply redistribution from rich to poor. Although laborintensive growth improves the relative standing of the poor, its main effect on poverty is given by its beneficial impact on their absolute income.

From a positive perspective, these results may help understand the considerable disparity in the poverty reaction to economic growth and, in particular, why in some circumstances poverty is irresponsive to production improvements. This would be the case of, for instance, a country experiencing a mining or oil boom that is unaccompanied by growth in other sectors. From a normative perspective, this study does not provide grounds for "industrial" (or selective) policies as it does not deal with the sources of 
sectoral growth, the complex links across sectors, or the political economy of government intervention. Instead, the results of the paper suggest that policy distortions that discourage labor employment or induce capital-biased technological innovation are illadvised to reduce poverty. Removing biases against labor, whether policy-induced or not, can effectively create opportunities for the poor in growing economic activities and, thus, help them break away from their condition. 


\section{References}

Attanasio, Orazio P., and Miguel Szekely, 1998, "Household Savings and Income Distribution in Mexico,” Working Paper No.390, Inter-American Development Bank, Research Department.

Besley, Timothy, and Robin Burgess, 2003. "Having Global Poverty," Journal of Economic Perspectives, 17(3), pp. 3-22.

Bibi, Sami, 2005. "When is Economic Growth Pro-Poor? Evidence from Tunisia," Cahier de recherche/Working Paper 05-22, CIRPEE.

Bourguignon, Francois, 2003. "The Growth Elasticity of Poverty Reduction: Explaining Heterogeneity Across Countries and Time Periods,” in Inequality and Growth: Theory and Policy Implications, Theo S. Eicher, and Stephen J. Turnovsky eds., MIT Press; Cambridge, MA.

Contreras, Dante, 2001. "Economic Growth and Poverty Reduction by Region: Chile 1990-96,” Development Policy Review, 19(3), pp.291-302.

Deaton, Angus, 2003. "Measuring Poverty in a Growing World (or Measuring Growth in a Poor World),” NBER Working Paper No. 9822.

Dollar, David, and Aart Kraay, 2002. "Growth is Good for the Poor," Journal of Economic Growth, 7(3), pp. 195-225.

Kakwani, Nanak, Shahid Khandker, and Hyun H. Son, 2004. "Pro-Poor Growth: Concepts and Measurement with Country Case Studies,” UNDP International Poverty Center, Working Paper No.1, Brazil.

Khan, Haider, 1999. "Sectoral Growth and Poverty Alleviation: A Multiplier Decomposition Technique Applied to South Africa,” World Development, 27(3), pp. 521530.

Kraay, Aart, 2005. "When is Growth Pro-Poor? Evidence from a Panel of Countries," Forthcoming, Journal of Development Economics.

Lopez, J. Humberto, 2004. "Pro-Growth, Pro-Poor: Is There a Tradeoff?” Policy Research paper No. 3378, World Bank, Washington, D.C.

Lucas, Sarah, and Peter Timmer, 2005. "Connecting the Poor to Economic Growth: Eight Key Questions,” Working Paper, Center for Global Development, Washington, D.C.

Menezes-Filho, Naercio, and Ligia Vasconcellos, 2004, “Operationalising Pro-Poor Growth: A Country Case Study on Brazil," Paper in the Operationalising Pro-Poor Growth Work Programme Series by AFD, BMZ, DFID and the World Bank. 
Miyagiwa, K. and Papageorgiou, C. (2005). “The elasticity of substitution, Hick’s conjecture and economic growth”, Working Paper, Department of Economics, Lousiana State University.

Ravallion, Martin, 2004. "Pro-Poor Growth: A Primer,” Policy Research paper No.3242, World Bank, Washington, D.C.

Ravallion, Martin, and Gaurav Datt, 1996. "How Important to India's Poor Is the Sectoral Composition of Economic Growth?” The World Bank Economic Review, 10(1), pp.1-25.

Ravallion, Martin, and Gaurav Datt, 2002. "Why Has Economic Growth Been More ProPoor in Some States of India than Others?” Journal of Development Economics, 68(2), pp. 381-400.

Ravallion, Martin, and Shaohua Chen, 2004. "China's (Uneven) Progress Against Poverty,” Policy Research paper No. 3408, World Bank, Washington, D.C.

Schmidt-Hebbel K., and Serven, L., 1999. "Saving in the world: the stylized facts?" in The Economics of Savings and Growth: Theory, Evidence, and Implications for Policy, K. Schmidt-Hebbel, and L.Serven eds. Cambridge University Press; Cambridge, New York and Melbourne, pp. 6-32.

Thorbecke, Eric, and Hong-Sang Jung, 1996. “A Multiplier Decomposition Method to Analyze Poverty Alleviation,” Journal of Development Economics, 48(2), pp. 279-300. 
Table 1. Poverty Reduction and Sectoral Growth: 3-Sector Disaggregation

In all regressions, the dependent variable is the annualized growth rate of the headcount poverty index during the longest spell available for each country. The independent variables are individual sector's per capita value added growth weighted by the share of this sector's value added in total GDP. In the fully constrained regression, all sectors are forced to have a common coefficient. The test presented at the bottom of the unconstrained regression support this restriction.

Full Sample with 3-sector data Unconstrained Fully constrained

(1)

\begin{tabular}{lcccc}
\hline \hline & & & & \\
Agriculture growth & -3.718 & $-1.470^{* *}$ & -5.351 & $-1.359^{* *}$ \\
(per capita, share-weighted) & $(3.647)$ & $(0.582)$ & $(6.119)$ & $(0.638)$ \\
Industry growth & -2.343 & $-1.470^{* *}$ & -2.420 & $-1.359^{* *}$ \\
(per capita, share-weighted) & $(1.636)$ & $(0.582)$ & $(1.738)$ & $(0.638)$ \\
Services growth & 0.167 & $-1.470^{* *}$ & 0.591 & $-1.359^{* *}$ \\
(per capita, share-weighted) & $(2.041)$ & $(0.582)$ & $(2.135)$ & $(0.638)$ \\
Constant & 0.006 & 0.015 & -0.000 & 0.010 \\
& $(0.020)$ & $(0.017)$ & $(0.022)$ & $(0.018)$ \\
\hline Test & $\beta_{\mathrm{AG}}=\beta_{\mathrm{IND}}=\beta_{\mathrm{SER}}$ & & $\beta_{\mathrm{AG}}=\beta_{\mathrm{IND}}=\beta_{\mathrm{SER}}$ & 0.51 \\
Test p-value & 0.62 & & 51 & 51 \\
\hline Observations & 55 & 55 & 0.12 & -- \\
R-squared & 0.13 & -- & & \multirow{2}{*}{} \\
\hline \hline
\end{tabular}

Full sample with 6-sector Data Unconstrained Fully constrained (3)

(4)

Numbers in parentheses are robust standard errors.

${ }^{*}$ significant at $10 \%$; ${ }^{* *}$ significant at $5 \%$; ${ }^{* * *}$ significant at $1 \%$ 


\begin{tabular}{|c|c|c|c|c|}
\hline & \multicolumn{2}{|c|}{ Full sample } & \multicolumn{2}{|c|}{ Reduced sample } \\
\hline & $\begin{array}{c}\text { Unconstrained } \\
\text { (1) }\end{array}$ & $\begin{array}{l}\text { Partially constrained } \\
\text { (2) }\end{array}$ & $\begin{array}{c}\text { Unconstrained } \\
\text { (3) }\end{array}$ & $\begin{array}{c}\text { Partially constrained } \\
(4)\end{array}$ \\
\hline $\begin{array}{l}\text { Agriculture growth } \\
\text { (per capita, share-weighted) }\end{array}$ & $\begin{array}{r}-11.204 \\
(7.269)\end{array}$ & $\begin{array}{l}-4.119^{* *} \\
(1.629)\end{array}$ & $\begin{array}{r}-11.695 \\
(7.010)\end{array}$ & $\begin{array}{c}-3.416^{\star *} \\
(1.353)\end{array}$ \\
\hline $\begin{array}{l}\text { Mining growth } \\
\text { (per capita, share-weighted) }\end{array}$ & $\begin{array}{l}1.120 \\
(4.628)\end{array}$ & $\begin{array}{l}1.373 \\
(1.459)\end{array}$ & $\begin{array}{c}4.661 \\
(4.171)\end{array}$ & $\begin{array}{l}2.386 \\
(1.507)\end{array}$ \\
\hline $\begin{array}{l}\text { Manufacturing growth } \\
\text { (per capita, share-weighted) }\end{array}$ & $\begin{array}{l}-3.829^{\star} \\
(2.175)\end{array}$ & $\begin{array}{l}-4.119^{* *} \\
(1.629)\end{array}$ & $\begin{array}{c}-3.624^{* *} \\
(1.422)\end{array}$ & $\begin{array}{c}-3.416^{* *} \\
(1.353)\end{array}$ \\
\hline $\begin{array}{l}\text { Utilities growth } \\
\text { (per capita, share-weighted) }\end{array}$ & $\begin{array}{l}10.726 \\
(9.605)\end{array}$ & $\begin{array}{c}1.373 \\
(1.459)\end{array}$ & $\begin{array}{l}12.329^{* *} \\
(5.651)\end{array}$ & $\begin{array}{l}2.386 \\
(1.507)\end{array}$ \\
\hline $\begin{array}{l}\text { Construction growth } \\
\text { (per capita, share-weighted) }\end{array}$ & $\begin{array}{l}-6.314 \\
(5.699)\end{array}$ & $\begin{array}{l}-4.119^{* *} \\
(1.629)\end{array}$ & $\begin{array}{l}-4.518 \\
(4.614)\end{array}$ & $\begin{array}{c}-3.416^{* *} \\
(1.353)\end{array}$ \\
\hline $\begin{array}{l}\text { Services growth } \\
\text { (per capita, share-weighted) }\end{array}$ & $\begin{array}{l}1.491 \\
(2.308)\end{array}$ & $\begin{array}{l}1.373 \\
(1.459)\end{array}$ & $\begin{array}{l}2.123 \\
(2.645)\end{array}$ & $\begin{array}{l}2.386 \\
(1.507)\end{array}$ \\
\hline Constant & $\begin{array}{l}-0.005 \\
(0.026) \\
\end{array}$ & $\begin{array}{c}0.001 \\
(0.019) \\
\end{array}$ & $\begin{array}{l}-0.036 \\
(0.022) \\
\end{array}$ & $\begin{array}{l}-0.031^{*} \\
(0.018) \\
\end{array}$ \\
\hline $\begin{array}{l}\text { Test } 1 \\
\text { Test } p \text {-value }\end{array}$ & $\begin{array}{c}\beta_{\mathrm{MIN}}=\beta_{\mathrm{U}}=\beta_{\mathrm{SER}} \\
0.65\end{array}$ & & $\begin{array}{c}\beta_{\mathrm{MIN}}=\beta_{\mathrm{U}}=\beta_{\mathrm{SER}} \\
0.43\end{array}$ & \\
\hline $\begin{array}{l}\text { Test } 2 \\
\text { Test } p \text {-value }\end{array}$ & $\begin{array}{c}\beta_{\mathrm{AG}}=\beta_{\mathrm{MA}}=\beta_{\mathrm{C}} \\
0.58\end{array}$ & & $\begin{array}{c}\beta_{A G}=\beta_{M A}=\beta_{C} \\
0.16\end{array}$ & \\
\hline $\begin{array}{l}\text { Test } 3 \\
\text { Test } p \text {-value } \\
\end{array}$ & & $\begin{array}{c}\beta_{\mathrm{AG}}=\beta_{\mathrm{MIN}} \\
0.06\end{array}$ & & $\begin{array}{c}\beta_{\mathrm{AG}}=\beta_{\mathrm{MIN}} \\
0.04\end{array}$ \\
\hline $\begin{array}{l}\text { Observations } \\
\text { R-squared }\end{array}$ & $\begin{array}{c}51 \\
0.17\end{array}$ & $\begin{array}{l}51 \\
--\end{array}$ & $\begin{array}{c}31 \\
0.29\end{array}$ & $\begin{array}{l}31 \\
--\end{array}$ \\
\hline
\end{tabular}




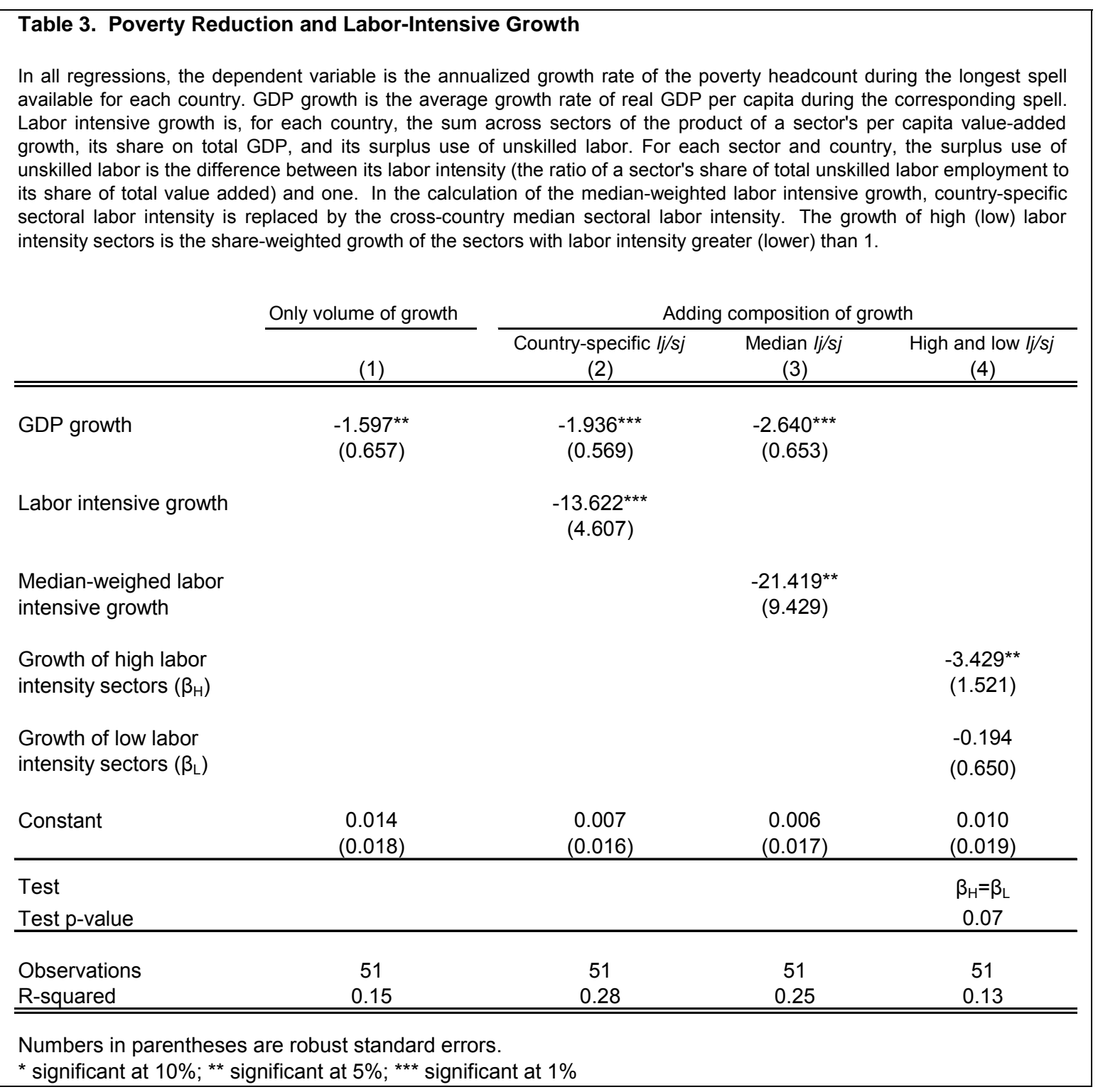




\begin{tabular}{|c|c|c|c|c|c|}
\hline \multicolumn{6}{|c|}{$\begin{array}{l}\text { In all regressions, the dependent variable is the annualized growth rate of the poverty headcount during the longest spell } \\
\text { available for each country. GDP growth is the average growth rate of real GDP per capita during the corresponding spell. } \\
\text { Labor intensive growth is, for each country, the sum across sectors of the product of a sector's per capita value-added } \\
\text { growth, its share on total GDP, and its surplus use of unskilled labor. For each sector and country, the surplus use of } \\
\text { unskilled labor is the difference between its labor intensity (the ratio of a sector's share of total unskilled labor employment } \\
\text { to its share of total value added) and one. Column (1) reproduces the benchmark regression for reference. In Column (2), } \\
\text { the measure of unskilled labor intensity did not trim the outliers. Column (3) shows the results obtained a procedure that is } \\
\text { robust to outliers. Column (4) reports the results obtained after dropping Argentina, Estonia, Latvia, and Senegal, the } \\
\text { largest outliers, from the sample. Column (5) shows the results obtained using the restricted sample that results from } \\
\text { applying the criteria in Kraay (2005). }\end{array}$} \\
\hline & $\begin{array}{c}\text { Benchmark } \\
\text { (1) }\end{array}$ & $\begin{array}{c}\text { Including Outliers } \\
\text { for lj/sj } \\
(2)\end{array}$ & $\begin{array}{l}\text { Robust to } \\
\text { Outliers } \\
\text { (3) }\end{array}$ & $\begin{array}{l}\text { Excluding } \\
\text { Outliers } \\
\text { (4) }\end{array}$ & $\begin{array}{l}\text { Reduced } \\
\text { Sample } \\
(5)\end{array}$ \\
\hline GDP growth & $\begin{array}{c}-1.936^{* * *} \\
(0.569)\end{array}$ & $\begin{array}{c}-1.872^{* * *} \\
(0.582)\end{array}$ & $\begin{array}{l}-2.134^{* * *} \\
(0.531)\end{array}$ & $\begin{array}{c}-2.483^{* * *} \\
(0.485)\end{array}$ & $\begin{array}{c}-1.754^{* * *} \\
(0.625)\end{array}$ \\
\hline Labor intensive growth & $\begin{array}{c}-13.622^{\star * *} \\
(4.607)\end{array}$ & $\begin{array}{c}-11.069^{* *} \\
(4.954)\end{array}$ & $\begin{array}{c}-13.174^{\star \star *} \\
(4.772)\end{array}$ & $\begin{array}{c}-13.147^{\star * *} \\
(4.274)\end{array}$ & $\begin{array}{c}-11.350^{* *} \\
(4.861)\end{array}$ \\
\hline Constant & $\begin{array}{c}0.007 \\
(0.016) \\
\end{array}$ & $\begin{array}{c}0.008 \\
(0.016) \\
\end{array}$ & $\begin{array}{c}0.008 \\
(0.016) \\
\end{array}$ & $\begin{array}{c}0.009 \\
(0.013) \\
\end{array}$ & $\begin{array}{l}-0.006 \\
(0.014) \\
\end{array}$ \\
\hline $\begin{array}{l}\text { Observations } \\
\text { R-squared }\end{array}$ & $\begin{array}{c}51 \\
0.28\end{array}$ & $\begin{array}{c}51 \\
0.25\end{array}$ & $\begin{array}{c}51 \\
0.29\end{array}$ & $\begin{array}{c}47 \\
0.48\end{array}$ & $\begin{array}{c}32 \\
0.31\end{array}$ \\
\hline $\begin{array}{l}\text { Numbers in parenth } \\
\text { * significant at } 10 \% \text {; ** }\end{array}$ & $\begin{array}{l}\text { bust sta } \\
\text { at } 5 \% ; * *\end{array}$ & $\begin{array}{l}\text { d errors. } \\
\text { ficant at } 1 \%\end{array}$ & & & \\
\hline
\end{tabular}




\section{Table 5. Allowing for Alternative Explanations}

In all regressions, the dependent variable is the annualized growth rate of the poverty headcount during the longest spell available for each country. GDP growth is the average growth rate of real GDP per capita during the corresponding spell. Labor intensive growth is, for each country, the sum across sectors of the product of a sector's per capita value-added growth, its share on total GDP, and its surplus use of unskilled labor. For each sector and country, the surplus use of unskilled labor is the difference between its labor intensity (the ratio of a sector's share of total unskilled labor employment to its share of total value added) and one. Column (1) controls for the (shareweighed) growth in agricultural value added. Column (2) controls for a direct effect of the Gini coefficient. Column (3) controls for potential interactions between the Gini inequality coefficient and, respectively, the volume and composition of growth. Column (4) controls for the growth in mean income (or expenditure) from household surveys. Column (5) accounts for the potential endogeneity of GDP growth using the weighted average GDP growth c

\section{Controlling for:}

\begin{tabular}{|c|c|c|c|c|}
\hline $\begin{array}{l}\text { Agricultural } \\
\text { growth }\end{array}$ & Inequality & $\begin{array}{l}\text { Interactions } \\
\text { with inequality }\end{array}$ & $\begin{array}{l}\text { Survey mean } \\
\text { growth }\end{array}$ & $\begin{array}{l}\text { Endogeneity of } \\
\text { GDP growth }\end{array}$ \\
\hline
\end{tabular}

$\begin{array}{lllll}(1) & (2) & (3) & (4) & \text { (5) }\end{array}$

\begin{tabular}{lccccc}
\hline \hline & & & & & \\
GDP growth & $-1.706^{* * *}$ & $-1.999^{* * *}$ & -1.309 & $-1.239^{*}$ & $-3.656^{* * *}$ \\
& $(0.635)$ & $(0.546)$ & $(2.040)$ & $(0.627)$ & $(0.772)$ \\
& & & & $-13)$ \\
Labor intensive growth & $-13.500^{* * *}$ & $-13.483^{* * *}$ & $-25.776^{*}$ & $-9.194^{* *}$ & $-17.557^{* * *}$ \\
& $(4.692)$ & $(4.718)$ & $(13.734)$ & $(4.218)$ & $(5.042)$
\end{tabular}

Agricultural growth $\quad-6.523$

(share-weighted) (6.123)

Gini*GDP growth $\quad-1.568$

(4.797)

27.726

Gini*Labor intensitive growth

(28.883)

Gini $\quad-0.001$

(0.001)

Survey mean growth $\quad-0.515^{\star * *}$

\begin{tabular}{|c|c|c|c|c|c|}
\hline \multirow[b]{2}{*}{ Constant } & & & \multicolumn{3}{|c|}{$(0.162)$} \\
\hline & $\begin{array}{c}0.006 \\
(0.017) \\
\end{array}$ & $\begin{array}{c}0.059 \\
(0.047) \\
\end{array}$ & $\begin{array}{c}0.007 \\
(0.017) \\
\end{array}$ & $\begin{array}{c}0.005 \\
(0.015) \\
\end{array}$ & $\begin{array}{c}0.035^{*} \\
(0.021) \\
\end{array}$ \\
\hline Observations & 51 & 51 & 51 & 51 & 50 \\
\hline R-squared & 0.30 & 0.30 & 0.30 & 0.44 & \\
\hline
\end{tabular}

Numbers in parentheses are robust standard errors.

${ }^{*}$ significant at $10 \% ;{ }^{* *}$ significant at $5 \% ;{ }^{* * *}$ significant at $1 \%$ 


\section{Table 6. Using Alternative Poverty Measures}

In all regressions, the dependent variable is the annualized growth rate of the corresponding poverty measure indicated below during the longest spell available for each country. GDP growth is the average growth rate of real GDP per capita during the corresponding spell. Labor intensive growth is, for each country, the sum across sectors of the product of a sector's per capita value-added growth, its share on total GDP, and its surplus use of unskilled labor. For each sector and country, the surplus use of unskilled labor is the difference between its labor intensity (the ratio of a sector's share of total unskilled labor employment to its share of total value added) and one. In columns (1)-(3), the poverty measure is the (average) poverty gap, the (average) squared poverty gap, and the Watt's index, respectively. In column (4) the poverty measure is the headcount poverty index, as in the benchmark regression; however, in this column, the growth of the poverty gap is used to control for the mean income of the poor.

Alternative poverty measure:

\begin{tabular}{|c|c|c|c|c|}
\hline & & \multirow[b]{2}{*}{$\begin{array}{c}\text { Controlling for } \\
\text { Poverty Gap } \\
(4) \\
\end{array}$} \\
\hline & $\begin{array}{l}\text { Poverty } \\
\text { Gap } \\
\text { (1) }\end{array}$ & $\begin{array}{l}\text { Squared } \\
\text { Poverty } \\
\text { Gap } \\
\text { (2) }\end{array}$ & $\begin{array}{l}\text { Watt's Poverty } \\
\text { Index } \\
\text { (3) }\end{array}$ & \\
\hline GDP growth & $\begin{array}{c}-2.068^{\star * \star} \\
(0.725)\end{array}$ & $\begin{array}{c}-5.283^{\star \star} \\
(2.430)\end{array}$ & $\begin{array}{c}-4.228^{\star *} \\
(1.658)\end{array}$ & $\begin{array}{c}-0.513^{\star \star *} \\
(0.175)\end{array}$ \\
\hline Labor intensitve growth & $\begin{array}{c}-14.220^{* *} \\
(6.940)\end{array}$ & $\begin{array}{c}-29.159^{* *} \\
(12.588)\end{array}$ & $\begin{array}{c}-24.260^{\star *} \\
(10.478)\end{array}$ & $\begin{array}{c}-3.830^{\star *} \\
(1.782)\end{array}$ \\
\hline Growth of poverty gap & & & & $\begin{array}{c}0.689^{* * *} \\
(0.048)\end{array}$ \\
\hline Constant & $\begin{array}{c}0.017 \\
(0.025) \\
\end{array}$ & $\begin{array}{c}0.079 \\
(0.062) \\
\end{array}$ & $\begin{array}{c}0.058 \\
(0.046) \\
\end{array}$ & $\begin{array}{c}-0.004 \\
(0.005) \\
\end{array}$ \\
\hline $\begin{array}{l}\text { Observations } \\
\text { R-squared }\end{array}$ & $\begin{array}{c}51 \\
0.19\end{array}$ & $\begin{array}{c}51 \\
0.28\end{array}$ & $\begin{array}{c}51 \\
0.27\end{array}$ & $\begin{array}{c}51 \\
0.94\end{array}$ \\
\hline
\end{tabular}

Numbers in parentheses are robust standard errors.

${ }^{*}$ significant at $10 \%$; ${ }^{* *}$ significant at $5 \%$; ${ }^{* * *}$ significant at $1 \%$ 


\begin{tabular}{|c|c|c|c|c|}
\hline $\begin{array}{l}\text { In these regressions, } \\
\text { holding income distr } \\
\text { distribution of income } \\
\text { introduced by Datt an } \\
\text { we use in this pape } \\
\text { system, where the su } \\
\text { is restricted to be the } \\
\text { residual component } \\
\text { controlling for (Cols. } \\
\text { average growth rate } \\
\text { each country, the sum }\end{array}$ & $\begin{array}{l}\text { re decompo } \\
\text { unchanged } \\
\text { mean, and a } \\
\text { d implement } \\
\text { ined through } \\
\text { g coefficient } \\
\text { e coefficient } \\
\text { SURE estin } \\
\text { f outliers. R } \\
\text { during the } \\
\text { product of a }\end{array}$ & $\begin{array}{l}\text { into the port } \\
\text { enz curve), } \\
\text { pproximation } \\
\text { by Kraay ( } 20 \\
\text { seemingly-ur } \\
\text { the growth, } \\
\text { le benchmar } \\
\text { on is condu } \\
\text { rding the exp } \\
\text { esponding sp } \\
\text { tor's per cap }\end{array}$ & $\begin{array}{l}\text { ue to change } \\
\text { ortion due } \\
\text { lual. This is } \\
\text { the cross-s } \\
\text { d-regression } \\
\text { ution, and re } \\
\text { ession. (The } \\
\text { ignoring (Co } \\
\text { ory variables, } \\
\text { nd labor inte } \\
\text { lue-added gr }\end{array}$ & $\begin{array}{l}\text { mean income } \\
\text { anges in the } \\
\text { decomposition } \\
\text { on of countries } \\
\text { lation (SURE) } \\
\text { al components } \\
\text { fficients on the } \\
\text { and 2) and } \\
P \text { growth is the } \\
\text { growth is, for } \\
\text { its share on to }\end{array}$ \\
\hline & & & SURE - R & $t$ to Outliers \\
\hline & $\begin{array}{c}\text { Mean } \\
\text { Component } \\
(1) \\
\end{array}$ & $\begin{array}{l}\text { Distribution } \\
\text { Component } \\
(2) \\
\end{array}$ & $\begin{array}{c}\text { Mean } \\
\text { Component } \\
(3) \\
\end{array}$ & $\begin{array}{c}\text { Distribution } \\
\text { Component } \\
(4) \\
\end{array}$ \\
\hline GDP growth & $\begin{array}{c}-2.142^{* * *} \\
(0.425)\end{array}$ & $\begin{array}{c}0.005 \\
(0.360)\end{array}$ & $\begin{array}{c}-2.231^{* * *} \\
(0.253)\end{array}$ & $\begin{array}{c}0.041 \\
(0.265)\end{array}$ \\
\hline Labor intensive growth & $\begin{array}{c}-12.510^{* * *} \\
(3.792)\end{array}$ & $\begin{array}{l}-0.862 \\
(3.216)\end{array}$ & $\begin{array}{c}-8.586^{* * *} \\
(2.371)\end{array}$ & $\begin{array}{l}-4.318^{*} \\
(2.482)\end{array}$ \\
\hline Constant & $\begin{array}{l}-0.001 \\
(0.015) \\
\end{array}$ & $\begin{array}{c}0.003 \\
(0.012) \\
\end{array}$ & $\begin{array}{c}0.008 \\
(0.010) \\
\end{array}$ & $\begin{array}{l}-0.004 \\
(0.010) \\
\end{array}$ \\
\hline Observations & 49 & 49 & 48 & 48 \\
\hline
\end{tabular}


Figure 1. Cross-Country Distribution of Labor Intensity (li/si) per Sector

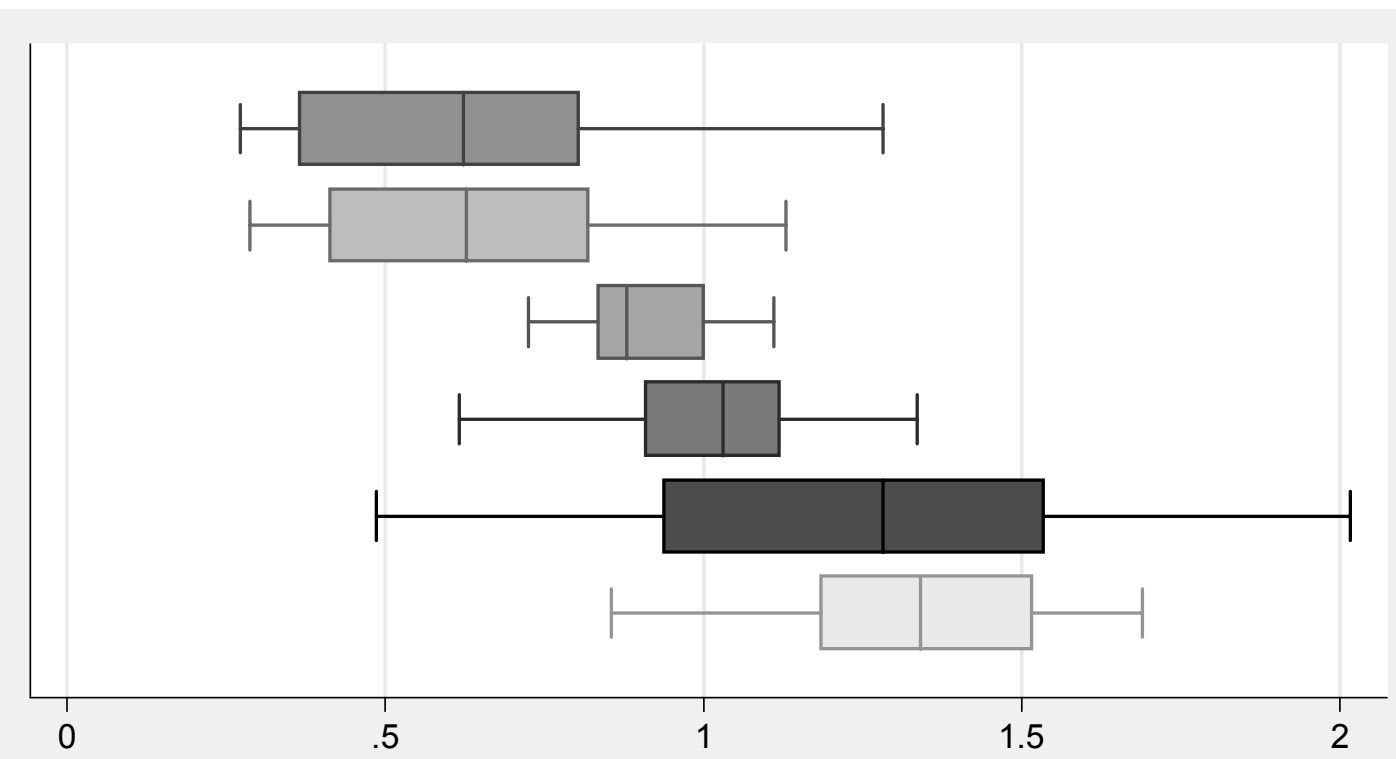

From top to bottom:

1. Mining

2. Utilities

3. Services

4. Manufacturing

5. Construction

6. Agriculture 
Figure 2. Poverty Change and Labor-Intensive Growth

Partial-regression observations, controlling for per capita GDP growth

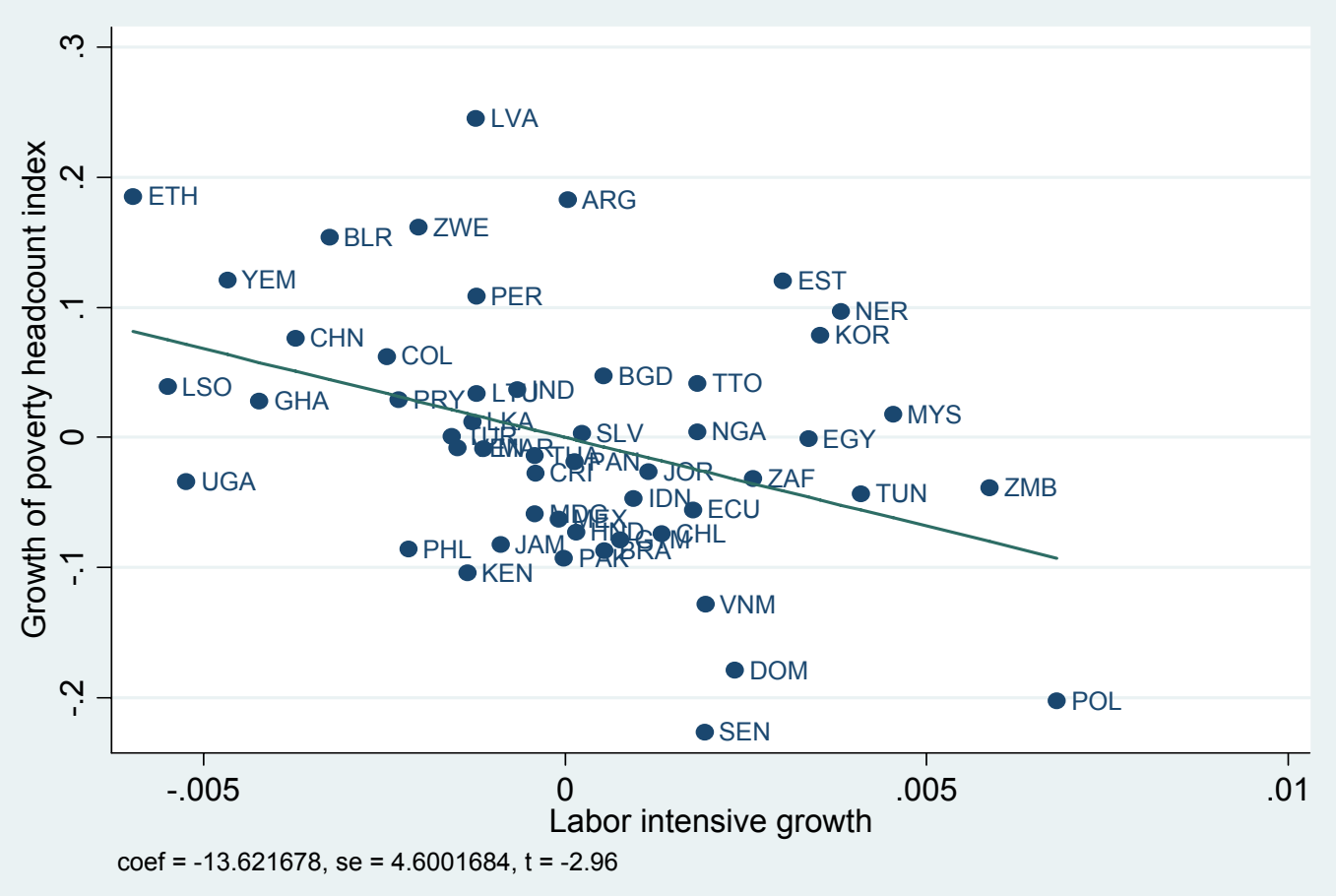




\begin{tabular}{|c|c|c|c|c|c|c|}
\hline WB Code & Country Name & Spell & $\begin{array}{c}\text { 3-sector data } \\
\text { (55-countries) }\end{array}$ & $\begin{array}{c}\text { 6-sector data } \\
\text { (51-countries) }\end{array}$ & $\begin{array}{l}\text { Non-outliers } \\
\text { (47-countries) }\end{array}$ & $\begin{array}{l}\text { Kraay's criteria } \\
\text { (32-countries) }\end{array}$ \\
\hline$\overline{\text { ARG }}$ & Argentina & $1992-1998$ & $\sqrt{ }$ & $\sqrt{ }$ & & \\
\hline BDI & Burundi & $1992-1998$ & $\sqrt{ }$ & & & \\
\hline BGD & Bangladesh & $1984-1992$ & $\sqrt{ }$ & $\sqrt{ }$ & $\sqrt{ }$ & $\sqrt{ }$ \\
\hline BLR & Belarus & $1988-1995$ & $\sqrt{ }$ & $\sqrt{ }$ & $\sqrt{ }$ & \\
\hline BRA & Brazil & $1985-1998$ & $\sqrt{ }$ & $\sqrt{ }$ & $\sqrt{ }$ & $\sqrt{ }$ \\
\hline $\mathrm{CHL}$ & Chile & $1987-1998$ & $\sqrt{ }$ & $\sqrt{ }$ & $\sqrt{ }$ & \\
\hline $\mathrm{CHN}$ & China & $1990-1998$ & $\sqrt{ }$ & $\sqrt{ }$ & $\sqrt{ }$ & $\sqrt{ }$ \\
\hline $\mathrm{COL}$ & Colombia & $1988-1998$ & $\sqrt{ }$ & $\sqrt{ }$ & $\sqrt{ }$ & $\sqrt{ }$ \\
\hline CRI & Costa Rica & $1993-1996$ & $\sqrt{ }$ & $\sqrt{ }$ & $\sqrt{ }$ & \\
\hline DOM & Dominican Republic & $1989-1998$ & $\sqrt{ }$ & $\sqrt{ }$ & $\sqrt{ }$ & \\
\hline DZA & Algeria & $1988-1995$ & $\sqrt{ }$ & & & \\
\hline ECU & Ecuador & $1988-1995$ & $\sqrt{ }$ & $\sqrt{ }$ & $\sqrt{ }$ & $\sqrt{ }$ \\
\hline EGY & Egypt & $1991-1999$ & $\sqrt{ }$ & $\sqrt{ }$ & $\sqrt{ }$ & $\sqrt{ }$ \\
\hline EST & Estonia & $1993-1995$ & $\sqrt{ }$ & $\sqrt{ }$ & & \\
\hline ETH & Ethiopia & $1995-2000$ & $\sqrt{ }$ & $\sqrt{ }$ & $\sqrt{ }$ & $\sqrt{ }$ \\
\hline GHA & Ghana & $1987-1999$ & $\sqrt{ }$ & $\sqrt{ }$ & $\sqrt{ }$ & $\sqrt{ }$ \\
\hline GTM & Guatemala & $1987-1989$ & $\sqrt{ }$ & $\sqrt{ }$ & $\sqrt{ }$ & \\
\hline HND & Honduras & $1989-1998$ & $\sqrt{ }$ & $\sqrt{ }$ & $\sqrt{ }$ & $\sqrt{ }$ \\
\hline IDN & Indonesia & $1987-2000$ & $\sqrt{ }$ & $\sqrt{ }$ & $\sqrt{ }$ & $\sqrt{ }$ \\
\hline IND & India & $1983-1997$ & $\sqrt{ }$ & $\sqrt{ }$ & $\sqrt{ }$ & $\sqrt{ }$ \\
\hline JAM & Jamaica & $1988-2000$ & $\sqrt{ }$ & $\sqrt{ }$ & $\sqrt{ }$ & \\
\hline JOR & Jordan & $1987-1997$ & $\sqrt{ }$ & $\sqrt{ }$ & $\sqrt{ }$ & \\
\hline KEN & Kenya & $1992-1997$ & $\sqrt{ }$ & $\sqrt{ }$ & $\sqrt{ }$ & $\sqrt{ }$ \\
\hline KOR & Korea, Rep. & $1988-1993$ & $\sqrt{ }$ & $\sqrt{ }$ & $\sqrt{ }$ & \\
\hline LKA & Sri Lanka & $1985-1995$ & $\sqrt{ }$ & $\sqrt{ }$ & $\sqrt{ }$ & $\sqrt{ }$ \\
\hline LSO & Lesotho & $1986-1995$ & $\sqrt{ }$ & $\sqrt{ }$ & $\sqrt{ }$ & $\sqrt{ }$ \\
\hline LTU & Lithuania & $1996-2000$ & $\sqrt{ }$ & $\sqrt{ }$ & $\sqrt{ }$ & \\
\hline LVA & Lativa & $1993-1998$ & $\sqrt{ }$ & $\sqrt{ }$ & & \\
\hline MAR & Morocco & $1985-1999$ & $\sqrt{ }$ & $\sqrt{ }$ & $\sqrt{ }$ & $\sqrt{ }$ \\
\hline MDG & Madagascar & $1993-1999$ & $\sqrt{ }$ & $\sqrt{ }$ & $\sqrt{ }$ & $\sqrt{ }$ \\
\hline MEX & Mexico & $1989-1998$ & $\sqrt{ }$ & $\sqrt{ }$ & $\sqrt{ }$ & $\sqrt{ }$ \\
\hline MLI & Mali & $1989-1994$ & $\sqrt{ }$ & & & \\
\hline MRT & Mauritania & $1988-1995$ & $\sqrt{ }$ & & & \\
\hline MYS & Malaysia & $1984-1997$ & $\sqrt{ }$ & $\sqrt{ }$ & $\sqrt{ }$ & $\sqrt{ }$ \\
\hline NER & Niger & $1992-1995$ & $\sqrt{ }$ & $\sqrt{ }$ & $\sqrt{ }$ & \\
\hline NGA & Nigeria & $1985-1997$ & $\sqrt{ }$ & $\sqrt{ }$ & $\sqrt{ }$ & $\sqrt{ }$ \\
\hline PAK & Pakistan & $1987-1998$ & $\sqrt{ }$ & $\sqrt{ }$ & $\sqrt{ }$ & $\sqrt{ }$ \\
\hline PAN & Panama & $1991-1996$ & $\sqrt{ }$ & $\sqrt{ }$ & $\sqrt{ }$ & $\sqrt{ }$ \\
\hline PER & Peru & $1985-1994$ & $\sqrt{ }$ & $\sqrt{ }$ & $\sqrt{ }$ & $\sqrt{ }$ \\
\hline $\mathrm{PHL}$ & Philippines & $1985-2000$ & $\sqrt{ }$ & $\sqrt{ }$ & $\sqrt{ }$ & $\sqrt{ }$ \\
\hline POL & Poland & $1993-1998$ & $\sqrt{ }$ & $\sqrt{ }$ & $\sqrt{ }$ & \\
\hline PRY & Paraguay & $1990-1998$ & $\sqrt{ }$ & $\sqrt{ }$ & $\sqrt{ }$ & $\sqrt{ }$ \\
\hline SEN & Senegal & $1991-1994$ & $\sqrt{ }$ & $\sqrt{ }$ & & \\
\hline SLV & El Salvador & $1989-1998$ & $\sqrt{ }$ & $\sqrt{ }$ & $\sqrt{ }$ & $\sqrt{ }$ \\
\hline THA & Thailand & $1988-2000$ & $\sqrt{ }$ & $\sqrt{ }$ & $\sqrt{ }$ & $\sqrt{ }$ \\
\hline TTO & Trinidad and Tobago & $1988-1992$ & $\sqrt{ }$ & $\sqrt{ }$ & $\sqrt{ }$ & \\
\hline TUN & Tunisia & $1985-1990$ & $\sqrt{ }$ & $\sqrt{ }$ & $\sqrt{ }$ & $\sqrt{ }$ \\
\hline TUR & Turkey & $1987-2000$ & $\sqrt{ }$ & $\sqrt{ }$ & $\sqrt{ }$ & \\
\hline UGA & Uganda & $1989-1996$ & $\sqrt{ }$ & $\sqrt{ }$ & $\sqrt{ }$ & $\sqrt{ }$ \\
\hline VEN & Venezuela & $1981-1998$ & $\sqrt{ }$ & $\sqrt{ }$ & $\sqrt{ }$ & $\sqrt{ }$ \\
\hline VNM & Vietnam & $1993-1998$ & $\sqrt{ }$ & $\sqrt{ }$ & $\sqrt{ }$ & $\sqrt{ }$ \\
\hline YEM & Yemen, Rep. & $1992-1998$ & $\sqrt{ }$ & $\sqrt{ }$ & $\sqrt{ }$ & $\sqrt{ }$ \\
\hline ZAF & South Africa & $1993-1995$ & $\sqrt{ }$ & $\sqrt{ }$ & $\sqrt{ }$ & \\
\hline ZMB & Zambia & $1991-1998$ & $\sqrt{ }$ & $\sqrt{ }$ & $\sqrt{ }$ & $\sqrt{ }$ \\
\hline ZWE & Zimbabwe & $1990-1995$ & $\sqrt{ }$ & $\sqrt{ }$ & $\sqrt{ }$ & \\
\hline
\end{tabular}




\begin{tabular}{|c|c|c|c|c|c|c|c|c|}
\hline \multicolumn{6}{|c|}{$\begin{array}{l}\text { Appendix 2. Descriptive Statistics for 51-Country Sample } \\
\text { Poverty Reduction and Sectoral Growth } \\
\text { (a) Univariate }\end{array}$} & & & \\
\hline variable & mean & median & $\min$ & $\max$ & sd & & & \\
\hline Growth in headcount poverty index & -0.014 & -0.028 & -0.279 & 0.267 & 0.106 & & & \\
\hline Industry growth & 0.008 & 0.004 & -0.018 & 0.070 & 0.014 & & & \\
\hline Agriculture growth* & 0.000 & 0.000 & -0.004 & 0.005 & 0.002 & & & \\
\hline Mining growth* & 0.000 & 0.000 & -0.014 & 0.016 & 0.004 & & & \\
\hline Manufacturing growth* & 0.005 & 0.003 & -0.006 & 0.046 & 0.009 & & & \\
\hline Utilities growth ${ }^{*}$ & 0.001 & 0.001 & -0.002 & 0.009 & 0.002 & & & \\
\hline Construction growth* & 0.002 & 0.001 & -0.003 & 0.016 & 0.003 & & & \\
\hline Services growth* & 0.010 & 0.009 & -0.018 & 0.033 & 0.011 & & & \\
\hline \multicolumn{9}{|l|}{ (b) Bivariate Correlation } \\
\hline variable & $\begin{array}{l}\text { Growth in } \\
\text { head-count } \\
\text { poverty } \\
\text { index }\end{array}$ & $\begin{array}{l}\text { Industry } \\
\text { growth }\end{array}$ & $\begin{array}{l}\text { Agricul- } \\
\text { ture } \\
\text { growth* }\end{array}$ & $\begin{array}{l}\text { Mining } \\
\text { growth* }\end{array}$ & $\begin{array}{c}\text { Manu- } \\
\text { facturing } \\
\text { growth* }\end{array}$ & $\begin{array}{l}\text { Utilities } \\
\text { growth* }\end{array}$ & $\begin{array}{l}\text { Construc- } \\
\text { tion growth* }\end{array}$ & $\begin{array}{r}\text { Services } \\
\text { growth }^{*}\end{array}$ \\
\hline Growth in headcount poverty index & 1.00 & & & & & & & \\
\hline Industry growth & -0.32 & 1.00 & & & & & & \\
\hline Agriculture growth* & -0.28 & 0.42 & 1.00 & & & & & \\
\hline Mining growth* & -0.12 & 0.58 & 0.41 & 1.00 & & & & \\
\hline Manufacturing growth* & -0.31 & 0.91 & 0.31 & 0.32 & 1.00 & & & \\
\hline Utilities growth* & -0.11 & 0.61 & 0.23 & 0.17 & 0.56 & 1.00 & & \\
\hline Construction growth* & -0.20 & 0.52 & 0.05 & 0.15 & 0.41 & 0.40 & 1.00 & \\
\hline Services growth* & -0.13 & 0.60 & 0.14 & 0.32 & 0.57 & 0.30 & 0.57 & 1.00 \\
\hline
\end{tabular}




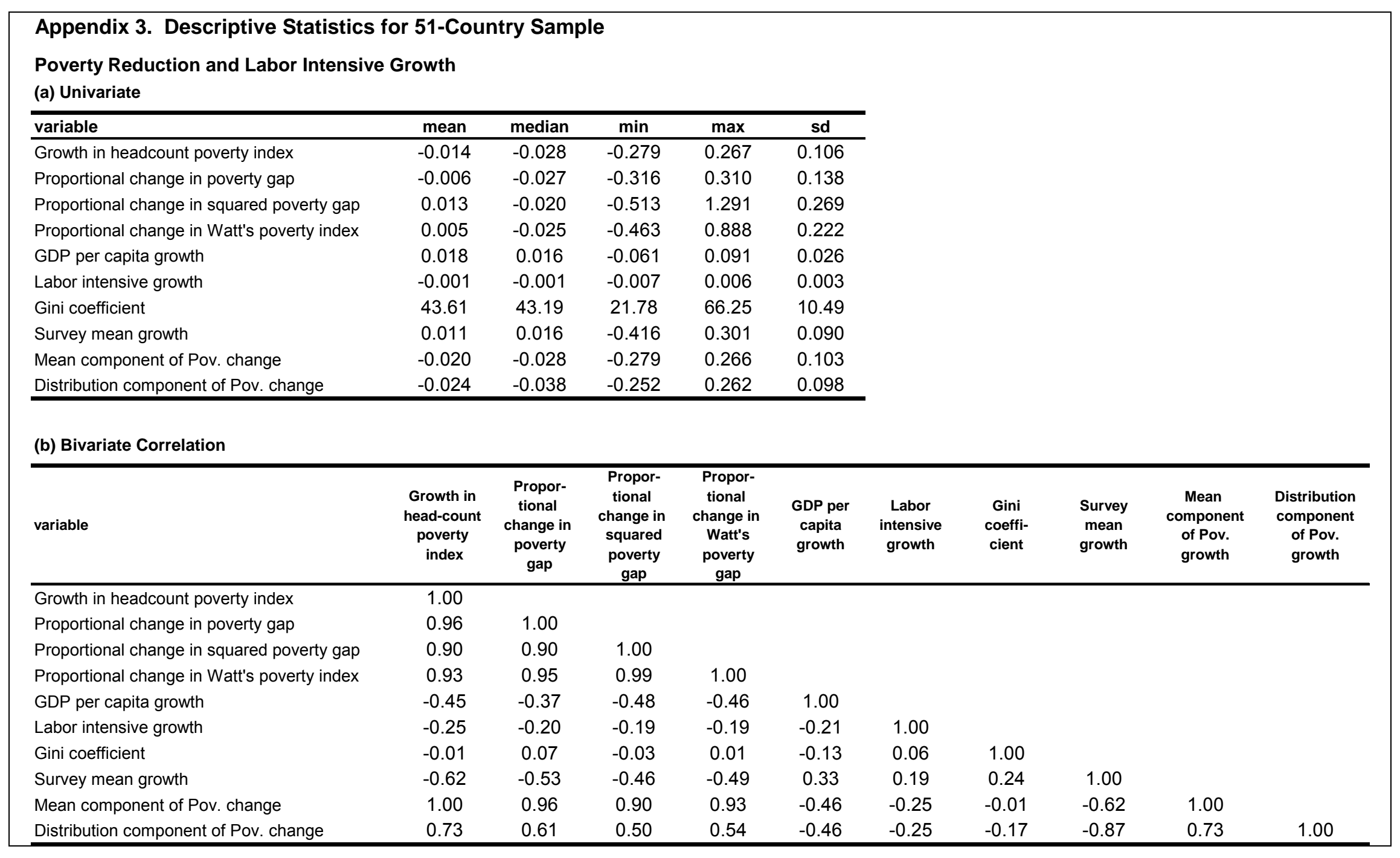

